\title{
Arsenic in Gold Mine Tailing and Agricultural Soil in Buru Island of Maluku
}

\author{
Reginawanti Hindersah',2), Agustinus Marthin Kalay3), Robby Risamasu3), \\ dan Triani Dewi ${ }^{4}$ )
}

\author{
1)Departemen Ilmu Tanah dan Sumberdaya Lahan, Fakultas Pertanian Universitas Padjadjaran \\ 2) Maluku Corner Centre of Excellence, Universitas Padjadjaran, Jalan Dipati Ukur 42 Bandung 40132 \\ 3) Faculty of Agriculture Universitas Pattimura, Jalan Ir. Putuhena Kampus Poka Ambon 97233 \\ 4) Agricultural Environment Research Centre, Jalan Raya Jakenan-Jaken KM 5, Jakenan, Pati 59182
}

Korespondensi: reginawanti@unpad.ac.id

\begin{abstract}
Contamination of heavy metal including Arsenic (As) due to mining activities decreased ecosystem quality. The objective of this study was to determine the arsenic level of tailing and agricultural soil, and evaluate the spatial distribution of As in closed gold mine and nearby agricultural area in Buru Sub-district of Maluku. Tailing and soil samples were taken by purposive method based on mining and agricultural activities. Arsenic level in tailing and soil samples was determined by Atomic Adsorption Spectrophotometer after mixed acid extraction. The study showed that gold mine increased As level in the top soil and tailing but soil of nearby agricultural area was not contaminated by As. Increased concentration of As in tailings has been verified. $\mathrm{pH}$ level of the agricultural area was neutral hence lowered As availability for plant.
\end{abstract}

Key words: Arsenic, Gold mine, Soil, Spatial distribution, Tailing

\section{INTRODUCTION}

The anthropogenic activities and global development cause environmental pollution that affects the quality of agriculture ecosystems. Heavy metal contaminations due to mining are reported elsewhere. Increased level of toxic heavy metal arsenic (As), cadmium $(\mathrm{Cd})$, nickel $(\mathrm{Ni})$, lead $(\mathrm{Pb})$, copper $(\mathrm{Cu})$, zinc $(\mathrm{Zn})$, cobalt $(\mathrm{Co})$ and mercury $(\mathrm{Hg})$ was detected in gold mining area in Portugal (da Silva et. al., 2004). Soil under plant succe-ssor contains $\mathrm{Pb}, \mathrm{Zn}$ and $\mathrm{Co}$ in the closed lead mine in Zaida of Marocco (Baghdad et. al., 2006). In Indonesia, increased level of heavy metal in mine area has been studied. Lead content in water dan total soluble solid exceeded the standard quality for heavy metal in environment but $\mathrm{Cd}$ and $\mathrm{Zn}$ content were below said standard (Wahyuni et al., 2013). Enrichment factor of $\mathrm{Pb}$ verified that the closed bauxite mining was heavily polluted but the area was only moderately contaminated by chrom (Putra and Apriadi, 2013).

Gold mining by using mercury $(\mathrm{Hg}$ ) to extract the precious metal has been proven to contaminate soil that surrounds the mine. Tailing that contain heavy metal is a source of contamintion since tailing was disposed unproperly in certain mine area. Illegal gold mine in Botak Mountain of Buru Island in Maluku, Indonesia has been establish at the beginning of year 2010 and closed by local government at 2016. Illegal gold miner did not only throw tailings away into rivers but also piled it up in productive paddy fields. The previous study demonstrated that the level of $\mathrm{Hg}$ in the mine area and river nearby was 9.92 - $166.10 \mathrm{mg} / \mathrm{kg}$ but the $\mathrm{Hg}$ level in the topsoil of paddy field nearby was low (Hindersah et. al., 2018).

Based on the regulations of the Indonesian Ministry of Agriculture No. 1 year 2019, the most risky heavy metals in soil were $\mathrm{As}, \mathrm{Cd}, \mathrm{Cr}$, $\mathrm{Hg}$, and $\mathrm{Pb}$. The toxicity of the mentioned five heavy metals is classified as higher over other metals so that it will have negative consequences for public health (Tchounwou et. al., 2012). Naturally, the soil contains heavy metal originating from parent materials such as phosphate sediments rocks, conglomerate, and coal (Sukar, 2003; Alexakis and Gamvroula, 2014). Many scientist studied that the content of As in soil world was $0,1-40 \mathrm{mg} /$ 
$\mathrm{kg}$ depend on soil genesis and parent material (Alloway, 1995; Bradl, 2005).

Soil properties and heavy metal valence determine heavy metal concentration in plants. Acidity $(\mathrm{pH})$ and oxigen level in soil are important to change their availability. In the studied area, the dominant vegetation is lowland rice. The mobility of arsenic, such as other heavy metal, is might be limited by neutral soil of paddy field. In soil with the $\mathrm{pH}$ of $>5$, As become immobile (Smith and Huyck, 1999). Arsenat $\left(\mathrm{AsO}_{4}{ }^{3-}\right)$ is mobile and available in aerobic soil but only $15-40 \%$ will be available in waterlogging soil (Wan et. al., 2015).

High level of As in agricultural area will threaten the food web and plant production, so the study to delineate As level in abandoned gold mine is important. The objective of this study was to determine the arsenic level of tailing and agricultural soil near abandoned gold mine and delineates the arsenic in studied area for evaluating the As spatial distribution in studied area.

\section{METHODS}

The study was carried out in May-June 2016, a year after the mine is officially closed. The studied area was the closed gold mine of Botak Mountain in Buru Regency of Maluku Province (Fig.1), and in nearby agricultural area located in Waelata, Waeapo and Lolong Guba sub-district. The land use was mainly irrigated paddy field.

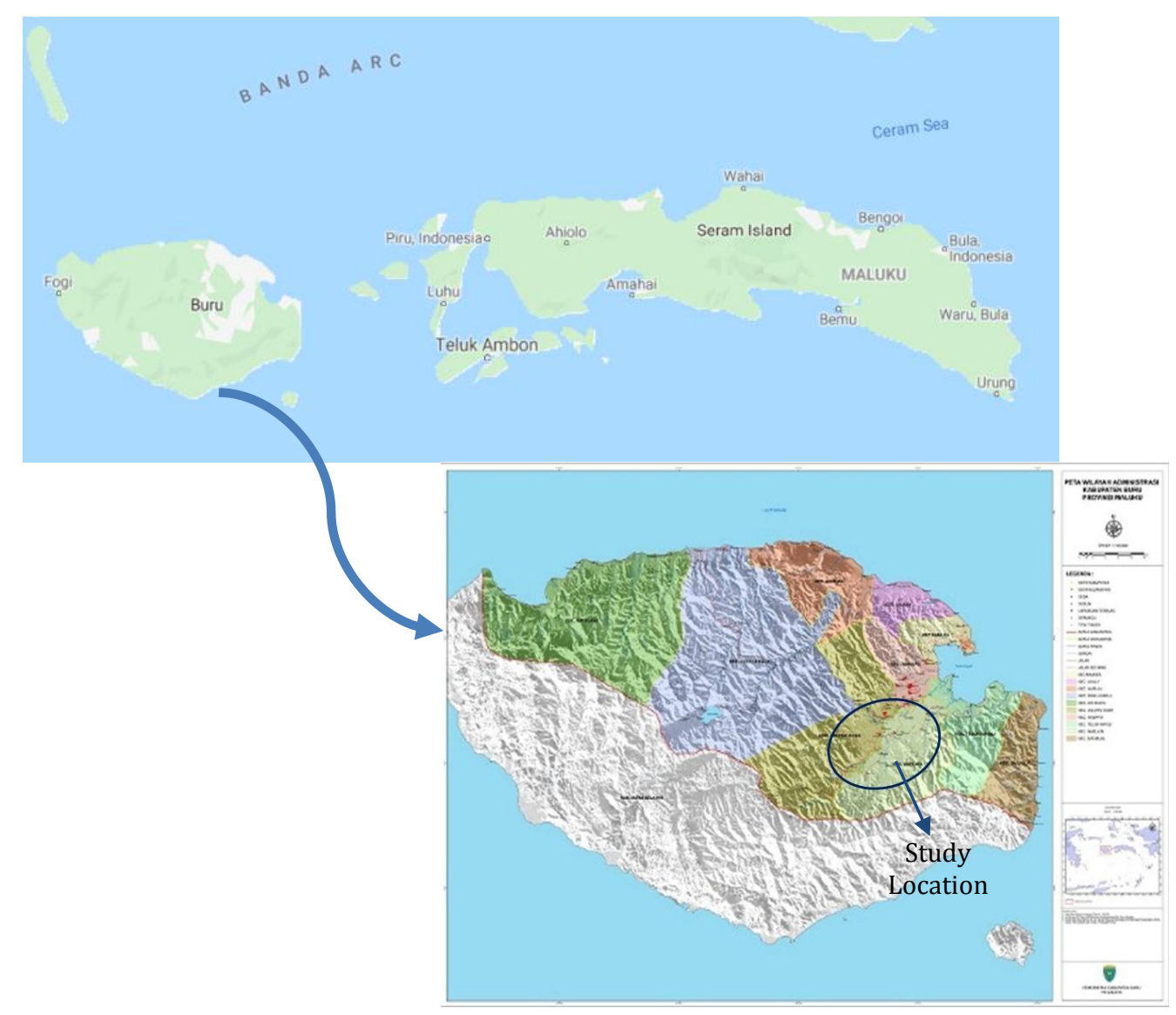

Figure 1 Study location in Gunung Botak of Buru Regency, Maluku Province and agricultural area nearby

A total of seven tailing and three soil samples were taken from the contaminated area and 71 soil sample were collected from agricultural soil. All sample collection location were selected by purposive method based on mining and agricultural activities in studied area. Tailing samples were collected from 60 $\mathrm{cm}$ depth by using auger while soil samples were taken up from top soil at the depth of 30 $\mathrm{cm}$. Weeds and litters at the surface of sam- 
pling spots was removed prior to collection. Tailing and soil sample were collected from 4 randomly sampling unit for each spot, then each composite sample was placed in plastic bag. In order to obtain homogenous sample, 1 $\mathrm{kg}$ of soil/tailing in the transparent plastic bag was mixed thoroughly prior to collection.

All soil samples were transported to Soil Laboratory of Agricultural Environment Research Centre in Pati, Central Java. Before As analysis, all soil samples were air dried and homogenized by grounding and passing through $0.5 \mathrm{~mm}$ sieve. A total of $5 \mathrm{mg}$ soil or tailings sample were extracted with $1 \mathrm{~mL}$ of perchloric acid p.a. and $5 \mathrm{~mL}$ of nitric acid p.a. (Nasir et. al., 2018). Total As content in tailings and soils were measured by Atomic Adsorption Spectrophotometry.

\section{RESULTS AND DISCUSSION}

Arsenic levels in soil where the miners piled gold tailing up were lower over tailing (Table 1). All location depicted in Tabel 1 were supposed to be contaminated by As according to the communities and miners. Critical As content in soil is $20-50 \mathrm{mg} / \mathrm{kg}$ (Alloway, 1995). Only one sampling plot has lower As level than critical content. Tailings collected from Waelo 1, Waelo 2, Parbulu and Migodo village have As level at the critical upper limit, $50 \mathrm{mg} / \mathrm{kg}$. The major mining site in Buru Subdistrict was Botak Mountain where the rocks is believed by the locals to contain high concentration of gold.

Batu and Gogorea Mountains were minor gold mines where the miners taken up loose rocks and sell it to the people at said subdistricts. Scattered and rocks heaps on topsoil can increase As level in top soil. Location 5-10 (Table 1) were agricultural field where the communities extract the gold from Botak Mountain material. The tailings were disposed on the paddy soil surface or into the manmade huge hole. This study showed that As level in the tailing from those location is high. Soil in agricultural area contained lower As concentration than contaminated site (Table 2).

Table 1 Arsenic level in soil and tailing in gold mine area

\begin{tabular}{clcc}
\hline Sampling plot & \multicolumn{1}{c}{ Location } & Kind of Sample & $\begin{array}{c}\text { Content of Arsenic } \\
(\mathrm{mg} / \mathrm{kg})\end{array}$ \\
\hline 1 & Wamsait village & Soil & 8.6 \\
2 & Batu Mountain & Soil & 20.1 \\
3 & Gogorea Mountain & Soil & 27.7 \\
4 & Botak Mountain & Tailing & 35.4 \\
5 & Paddy field Waelo & Tailing & 20.9 \\
6 & Waelo 1 Village* & Tailing & 47.0 \\
7 & Waelo 2 Village* & Tailing & 46.3 \\
8 & Anhoni Water shed & Tailing & 21.2 \\
9 & Parbulu Village* $^{*}$ & Tailing & 45.0 \\
10 & Migodo Village* $^{*}$ & Tailing & 44.8 \\
\hline
\end{tabular}

* Used for paddy field

Arsenic are found in igneous rocks that is formed through the cooling and solidification of magma from the active volcanoes. The parent material of soil of Buru Island was volcanic ash; Arsenic would be found in rocks of Buru Island. Normal arsenic levels in world soils are $0.1-40 \mathrm{mg} / \mathrm{kg}$ or $0.1-50 \mathrm{mg} / \mathrm{kg}$ (Alloway, 1995; Violante et. al., 2010). Although As in contaminated sites were increased, their mobility and availability are determined by soil $\mathrm{pH}$ and oxidationreduction reaction (Violante et. al., 2010).

Our previous study showed that soil acidity of studied location was 6.31-7.25 (Hindersah et. al., 2018). Arsen immobilization in soil is begun when soil $\mathrm{pH}>5$ (Smith and Huyck, 1999). The rice fields in Buru are saturated with water until 10 days before 
harvest. Arsenate $\left(\mathrm{AsO}_{4}{ }^{3-}\right)$ is mobile in aerobic soil but becomes less available for plants uptake in waterlogged soil (O'Neill, 1995). At aerobic condition, reduction of arsenate to arsenite by soil microbes reduced As mobility and limited plant uptake (Abbas et. al., 2018). The results, this study suggested that bioavailability of As in Buru Agricultural soil is low.

Table 2 Arsenic level in agricultural soil near closed gold mine area of Botak Mountain

\begin{tabular}{cccccc}
\hline No & $\begin{array}{c}\text { Sampling } \\
\text { Plot }\end{array}$ & $\begin{array}{c}\text { Arsenic } \\
(\mathrm{mg} / \mathrm{kg})\end{array}$ & No & $\begin{array}{c}\text { Sampling } \\
\text { Plot }\end{array}$ & $\begin{array}{c}\text { Arsenic } \\
(\mathrm{mg} / \mathrm{kg})\end{array}$ \\
\hline 1 & 11 & 30,40 & 37 & 67 & 1,91 \\
2 & 13 & 7,43 & 38 & 68 & 6,12 \\
3 & 14 & 24,12 & 39 & 69 & 6,28 \\
4 & 15 & 43,95 & 40 & 70 & 8,10 \\
5 & 22 & 53,97 & 41 & 79 & 9,30 \\
6 & 23 & 18,71 & 42 & 80 & 9,84 \\
7 & 26 & 9,20 & 43 & 81 & 12,19 \\
8 & 27 & 5,96 & 44 & 82 & 8,22 \\
9 & 28 & 3,99 & 45 & 84 & 19,65 \\
10 & 29 & 5,09 & 46 & 85 & 18,85 \\
11 & 30 & 5,75 & 47 & 86 & 11,79 \\
12 & 31 & 2,45 & 48 & 87 & 14,91 \\
13 & 33 & 6,00 & 49 & 88 & 10,79 \\
14 & 34 & 16,47 & 50 & 89 & 5,41 \\
15 & 35 & 5,04 & 51 & 90 & 7,06 \\
16 & 40 & 7,96 & 52 & 91 & 1,82 \\
17 & 43 & 6,77 & 53 & 92 & 3.17 \\
18 & 45 & 17,94 & 54 & 93 & Td \\
19 & 46 & 15,90 & 55 & 94 & 4,42 \\
20 & 47 & 13,75 & 56 & 95 & 1,82 \\
21 & 49 & 3,26 & 57 & 96 & 6,28 \\
22 & 50 & 4,27 & 58 & 97 & 7,64 \\
23 & 51 & 6,42 & 59 & 98 & 10,86 \\
24 & 52 & 10,74 & 60 & 99 & 20,63 \\
25 & 55 & 2,47 & 61 & 101 & 10,57 \\
25 & 56 & 15,05 & 62 & 102 & 13,04 \\
27 & 57 & 0,85 & 63 & 103 & 4,17 \\
28 & 58 & 6,26 & 64 & 104 & 11,54 \\
29 & 59 & 11,06 & 65 & 105 & 10,99 \\
30 & 60 & 3,10 & 66 & 106 & 16,03 \\
31 & 61 & 3,00 & 67 & 107 & 7,77 \\
32 & 62 & 8,61 & 68 & 108 & 6,80 \\
33 & 63 & 2,72 & 69 & 109 & 3,50 \\
34 & 64 & 6,68 & 70 & 110 & 9,46 \\
35 & 65 & 2,86 & 71 & 111 & 0,71 \\
36 & 66 & 2,51 & & & \\
\hline & & & & & \\
12 & & \\
14 & &
\end{tabular}

Based on As concentration in each sampling point, the simple map of As distribution was depicted in Fig 2. Arsenic level was divided to three categories i.e. low < $20 \mathrm{mg} / \mathrm{kg}$, medium (critical concentration) 20$50 \mathrm{mg} / \mathrm{kg}$ and high (contaminated level) $>50$ $\mathrm{mg} / \mathrm{kg}$. The map clearly showed that the high level of As was in the hot spot of gold mine of Botak Mountain. We found only one sampling point that have the strong pollution risk. The sampling area was in the Botak Mountain where the concentration of As was up to 53,97 $\mathrm{mg} / \mathrm{kg}$ (Table 2).

The presence of $20-50 \mathrm{mg} / \mathrm{kg}$ As in limited area of Waelata and Waeapo sub-district will possibly threten the production of food crops mainly rice in Buru. According to Kurniati et. al. (2019), agricultural sector contributed to one third of Buru's Gross Regional Domestic Products in 2016. In the study area, farmers grown food crops include rice, pulses, vegetable, tubers and fruits, but rice is a dominant and important crop for the communities as well as Buru Regency. Indonesian governence stated that Buru Regency is the centre of food (mainly rice) production in Eastern part of Indonesia. Comprehensive ecological risk assesment in Botak Maountain and agricultural area nearby should be carried out although the As level in agricultural area demonstrated no serious soil pollution of Arsenic. Hence, the communities might continue thei agricultural practice in the healthy soil.

\section{CONCLUSION}

Gold mine at Botak Mountain by rock crushing for gold extraction increases As levels in the top soil of contaminated area. However, As levels in agricultural land are low and might be considered as uncontaminated area. Gold mine tailings contain As at the upper limit of critical concentration. The presence of As in agricultural land doesn't threaten crop production because the neutral $\mathrm{pH}$ and waterlogging paddy soil limit As uptake by plant roots. 


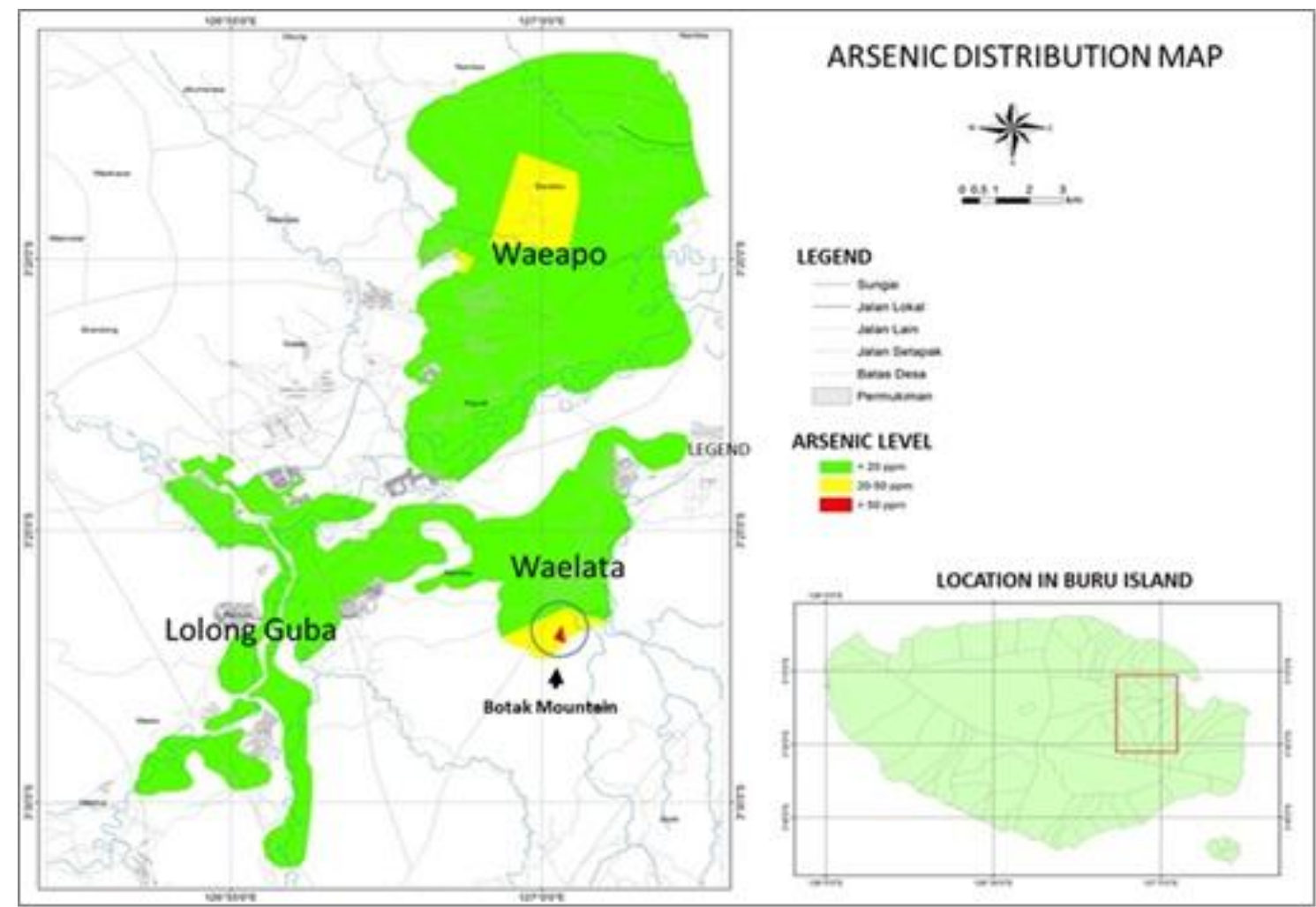

Figure 2 Spatial distribution of As in Waeapo, Waelata dan Lolong Guba Sub-district as well as in Botak Mountain.

\section{REFFERENCES}

Abbas, G., B. Murtaza, I. Bibi, M. Shahid, N.K. Niazi, M.I Khan, M.A. Amjad, M. Hussain, and Natasha. 2018. Arsenic uptake, toxicity, detoxification, and speciation in plants: physiological, biochemical, and molecular aspects. Int. J. Environ. Res. Public Health 15(1), 59.

Alexakis, D. and Gamvroula, D. 2014. Arsenic, chromium, and other potentially toxic elements in the rocks and sediments of Oropos-Kalamos Basin, Attica, Greece. Appl. Environ. Soil Sci. 2014: 1-8.

Alloway, B.J. 1995. The Origin of heavy metal in soil. In Alloway, B.J. (Ed.) Heavy Metals in Soil. Blackie Academic and Professional, Glasgow.

Baghdad, B., M. Naimi, A. Bouabdli, P. Sonnet and S. Lutts. 2006. Heavy metals in tailings, soils and vegetation of an abandoned lead mine land in Morocco. Ecol. Mediter. 32: 85-91.
Bradl, H. 2005. Heavy Metal in Environment: Origin, Interaction and Remediation, Volume 6. Academic Press. Amsteram.

Da Silva E.F., C. Zhang, L.S. Pinto, C. Patinha and P. Reis. 2004. Hazard assessment on arsenic and lead in soils of Castromil gold mining area, Portugal. Appl. Geochem. 19(6):887898.

Hindersah, R., R. Risamasu, A.M. Kalay, T. Dewi and I. Makatita. 2018. Mercury contamination in soil, tailing and plants on agricultural fields near closed gold mine in Buru Island, Maluku. J. Degr. mining Land Manag. 5(2):1027-1034.

Kurniati, N. 2019. Implementation of landreform policy on agricultural area of indigenous right (case study in South Buru Regency). Bina Hukum Lingkungan. 4(1): 153 - 171.

Nasir, M., Sulastri and M. M. Hilda. 2018. Analisis kadar logam timbal dan arsenik dalam tanah dengan spektrometri serapan atom. J. IPA Pembelajaran IPA 2(2): 89-99. 
O’Neill, P. 1995. Arsenic. In Alloway, B.J. (Ed.) Heavy Metals in Soils, 2nd edn. Blackie Academic and Profesional. Glasgow. p: 105-121

Putra, R. D. dan Apriadi, T. 2018. Studi kontaminasi logam berat $(\mathrm{Pb}$ dan $\mathrm{Cr}$ ) pasca pertambangan bauksit sebagai potensi lokasi kegiatan budidaya perikanan. Intek Akuakul. 2(1):1-15.

Smith, K. S. and Huyck, H.LO. 1999. An overview of the abundance, relative mobility, boiavaibility, and human toxicity of metals. In Plumlee, G.S. and Logson, M.J. (Eds.). The Environmental Chemistry of Mineral Deposits, Reviews in Economic Geology, Vol. 6A. Society of Economic Geologists, Inc. p. $29-70$.

Sukar. 2003. Sumber dan terjadinya arsen di lingkungan (review). J. Ekol. Kesehatan 2(2):232-238.

Tchounwou. P.B., C.G. Yedjou, A.K. Patlolla and D.J. Sutton. 2012. Heavy metals toxicity and the environment. In Luch A (Eds.) Molecular, Clinical and Environmental Toxicology. Experientia Suppl Vol 101. Springer, Basel. p.133-164.

Violante, A., V. Cozzolino, L. Perelomov, A.G. Caporale and M. Pigna. 2010. Mobility and bioavailability of heavy metals and metalloids in soil environments. J Soil. Sci. Plant. Nutr. 10 (3): 268-292.

Wahyuni, H., S.B. Sasongko dan D.P. Sasongko. 2013. Kandungan logam berat pada air, sedimen dan plankton di daerah penambangan masyarakat desa Batu Belubang Kabupaten Bangka Tengah. Dalam Sudharto, P.H. et. al. (Eds.). Prosiding Seminar Nasional Pengelolaan Sumberdaya Alam dan Lingkungan: Meningkatkan Peran Strategis Pengeloaan Sumberdaya Alam dan Lingkungan dalam Pembangunan Berkelanjutan. Program Studi Ilmu Lingkungan, Program Pascasarjana Universitas Dipenogoro. Semarang, 11 September 2012. Hal 488-494.

Wan, X., M. Lei, T-B. Chen, J. Yang, X. Zhou and G. Zhou. 2015. Impact of waterlogging on the uptake of arsenic by hyper- accumulator and tolerant plant. J. Chem. Ecol. 31(1): 53-63. 